\title{
Co-morbidity Factors Associated with Influenza in Nigeria
}

\author{
Aishatu B. Gubio*1, Saka J. Muhammad², Aisha Mamman³, Ado Zakari ${ }^{4}$ and Oladayo Biya ${ }^{1}$ \\ ${ }^{1}$ Nigeria Field Epidemiology and Laboratory Training Program (NFELTP), Federal Capital Territory, Nigeria; ${ }^{2}$ Department of \\ Epidemiology and community Health University of Ilorin, Faculty of Clinical Science, College of Medicine, Ibadan, Nigeria; ${ }^{3} \mathrm{Ahmadu}$ \\ Bello University Zaria, Zaria shika, Nigeria; ${ }^{4}$ Kaduna State Ministry of Health Kaduna, Kaduna, Nigeria
}

\section{Objective}

To analyze Influenza surveillance data from 2009 to 2010 the Northern, Southern, and Western zones in Nigeria and determined co-morbidity factors associated with influenza in Nigeria.

\section{Introduction}

Influenza is viral illness that affects mainly the nose, throat, bronchi and occasionally, the lungs. Influenza viruses have been an under-appreciated contributor to morbidity and mortality in Nigeria. They are a substantial contributor to respiratory disease burden in Nigeria and other developing countries. Nigeria started influenza sentinel surveillance in 2008 to inform disease control and prevention efforts.

\section{Methods}

We conducted a cross sectional study on secondary data analysis of Influenza surveillance data from January 2009 to December 2010 obtained from Nigeria's Federal Ministry of Health. Epidemiological data were obtained for suspected ILI and SARI cases defined in accordance with WHO Regional Office for Africa's guidelines. Laboratory confirmation for presence of influenza viruses was done using real time PCR assays.

Standardized case investigation forms used for sample collection were analyzed using Epi-Info software to generate frequency and proportions.

\section{Results}

Of the 5,860 suspected influenza cases reported between 2007 and 2011 from all the influenza sites in Nigeria, 1104 (18.8\%) and 2,510 $(42.8 \%)$ of the total cases were recorded in 2009 and 2010 respectively. A total of 296 (7.3\%) were positive for Flu A, while 147 (2.9\%) for Flu B. The Northern zone recorded a total of 1908(AR: 2.6/100,000) suspected cases while the Southern zone recorded 554(AR: 1.48/100,000) and the Western zone reported $549(2 / 100,000)$ suspected cases. Of the 443 that were positive 43 $(1.5 \%)$ were health workers, $446(8.0 \%)$ had co infection of chronic respiratory tract disease, $50(3.7 \%)$ had co infection with heart disease. Exposure to poultry was $2797(98.2 \%)$.

\section{Conclusions}

Co-morbidity factors associated with influenza viruses are an important contribution to the burden of respiratory illnesses in Nigeria predominantly affecting children less than 5years and adults 25 years and above. Additional years of data are needed to better understand the co-morbidity factors associated epidemiology of influenza viruses in Nigeria.
INFLUENZA AND CHRONIC OBSTRUCTIVE PULMONARY DISEASE (COPD)

\begin{tabular}{|c|c|c|c|}
\hline $\begin{array}{c}\text { INFLUENZA AND CHRONIC OBSTRUCTIVE } \\
\text { PULMONARY DISEASE (COPD) }\end{array}$ & $\begin{array}{c}\text { Influenza with } \\
\text { COPD N }(\%)\end{array}$ & $\begin{array}{c}\text { Influenza only } \\
\mathrm{N}(\%)\end{array}$ & Total \\
\hline $\mathrm{A} / \mathrm{H} 1$ & $0(0.0)$ & $12(100.0)$ & $12(100.0)$ \\
\hline $\mathrm{A} / \mathrm{H} 3$ & $10(11.2)$ & $79(88.8)$ & $89(100.0)$ \\
\hline $\mathrm{All}$ Negative & $551(11.1)$ & $4392(88.9)$ & $\begin{array}{c}4943 \\
(100.0)\end{array}$ \\
\hline $\mathrm{pdmA} / \mathrm{HIN} 1$ & $14(9.3)$ & $137(90.7)$ & $151(100.0)$ \\
\hline $\mathrm{pdmA} / \mathrm{H} 1 \mathrm{~N} 1$ & $10(5.6)$ & $170(99.4)$ & $180(100.0)$ \\
\hline Total & $585(10.9)$ & $4790(89.1)$ & $5375(100.0)$ \\
\hline
\end{tabular}

Only $585(10.9 \%)$ had chest indrawing, with majority of the influenza subtype pdm A/H1N1 cases $14(9.3 \%)$ had chest indrawing.

\section{INFLUENZA AND CHRONIC CHEST DISEASE}

\begin{tabular}{|c|c|c|c|}
\hline $\begin{array}{c}\text { Influenza } \\
\text { Sub-type }\end{array}$ & $\begin{array}{c}\text { Influenza with Chronic } \\
\text { Shortness of Breath N }(\%)\end{array}$ & $\begin{array}{c}\text { Influenza cases without Chronic } \\
\text { Shortness of Breath N(\%) }\end{array}$ & Total \\
\hline A/H1 & $0(0.0)$ & $16(100.0)$ & $16(100.0)$ \\
\hline A/H3 & $1(0.9)$ & $115(99.1)$ & $116(100.0)$ \\
\hline All Negative & $56(1.1)$ & $5204(98.9)$ & 5204 \\
& $0(1.3)$ & $152(98.7)$ & $152(100.0)$ \\
\hline pdm A/H1N1 & $0(0.0)$ & $181(100.0)$ & $181(100.0)$ \\
\hline Un-subtype-able & $57(1.0)$ & $5668(99.0)$ & $5725(100.0)$ \\
\hline Total & &
\end{tabular}

Less than $5 \%$ of the respondents with influenza cases had chronic shortness of breath

\section{Keywords}

Surveillance; Influenza; Nigeria; Co-morbidity

\section{Acknowledgments}

We would like to acknowledge and express our sincere gratitude to the personnel of the National Influenza Reference Laboratory, and the sentinel surveillance sites for assisting us technically during this write up. We would also like to thank the Federal Ministry of Health specifically epidemiology division for all the support to the sentinel surveillance site.

\section{References}

Oshin O. Enzyme immunoassay of antibodies to influenza A virus in Nigerian children. Trop Geogr Med. 1979;31:509-17

Njoku-Obi AN OO. Viral respiratory diseases in Nigeria: a serological survey. II Complement fixing antibody levels of influenza A, B and C and para-influenza 1. J Trop Med Hyg 1966;69:147-9

McCoy L et al. A multiple cause-of-death analysis of asthma mortality in the United States, 1990-2001.Journal of Asthma, 2005, 42:757-763.

Olaleye OD, Omilabu SA, Olabode AO and Fagbami AH. Serological evidence for influenza virus activity in Nigeria (1985-1987). Virologie 1989;40:11-7

Adams A et al. The influence of patient and doctor gender on diagnosing coronary heart disease.Sociology of Health and Illness, 2008, 30:118 .

\footnotetext{
*Aishatu B. Gubio

E-mail: yabintu@gmail.com
} 